Thus in the context of advanced neoplastic disease immunotherapy carried out by the method described provides a form of palliation for some patients. It does not offer a cure in these patients. Whether this method would improve the survival rate by killing all tumour cells in patients with only a small residual tumour load after surgery remains to be decided. Other aspects require investigation. What are the mechanisms of the tumour rejection observed? Is there an increase in the number of cytotoxic lymphocytes, is blocking factor (Hellström and Hellström, 1970a) reduced, are unblocking factors (Hellström and Hellström, 1970b; Bansal and Sjögren, 1971) produced? With a greater understanding of the mechanisms involved it might prove possible to design a more effective immunotherapeutic regimen by altering the constitution, frequency, and number of doses of vaccine. It might also prove possible to determine which patients are likely to derive most benefit from immunotherapy. It is, however, very unlikely that immunotherapy will ever replace other, conventional forms of therapy but it could become a useful adjunct to surgery, radiotherapy, and chemotherapy.

We wish to thank colleagues for referring patients for immunotherapy, particularly Mr. H. B. Torrance and Mr. T. B. Fitzgerald. We would also like to thank the research grants committee of the United Manchester Hospitals for supporting this project.

\section{References}

Bansal, S. C., and Sjögren, H. O. (1971). Nature New Biology, 233, 76. Brandes, L. J., Galton, D. A. G., and Wiltshaw, E. (1971). Lancet, 2, 293.
Currie, G. A., Lejeune, F., and Fairley, G. H. (1971). British Medical fournal, 2, 305.

Czajkowski, N. P., Rosenblatt, M., Wolf, P. L., and Vazquez, J. (1967). Lancet, 2, 905. Finney, J. W., Byers, E. H., and Wilson, R. H. (1960). Cancer Research, 20,

Foley, E. J. (1953). Cancer Research, 13, 835.

Gorer, P. A., and Kaliss, N. (1959). Cancer Research, 19, 824.

Graham, J. B., and Graham, R. M. (1959). Surgery, Gynecology and Obstetrics, $109,131$.

Graham, J. B., and Graham, R. M. (1962). Surgery, Gynecology and Obstetrics, $114,1$.

Guyer, R. J., and Crowther, D. (1969). British Medical fournal, 4, 406.

Hellström, I., Hellström, K. E., Pierce, G. E., and Yang, J. P. S. (1968).

Nature, 220, 1352.
Hellström, K. E., and Hellström, I. (1969). Advances in Cancer Research, $12,167$.

Hellström, K. E., and Hellström, I. (1970a). Annual Review of Microbiology,

24, 373.
Hellström, K. E., and Hellström, I. (1970b). International fournal of Cancer, 5, 195.

Ikonopisov, R. L., et al. (1970). British Medical fournal, 2, 752.

Kaliss, N. (1958). Cancer Research, 18, 992.

Kaliss, N., and Molomut, N. (1952). Cancer Research, 12, 110

Kellock, T. H., Chambers, H., and Russ, A. (1922). Lancet, 1, 217.

Klein, E. (1969). Cancer Research, 29, 2351.

Klein, G., Sjögren, H. O., Klein, E., and Hellström, K. E. (1960). Cancer Research, 20, 1561 .

Mathé, G. (1969). British Medical fournal, 4, 7

Mathé, G. (1970). British Medical fournal, 4, 787

Murray, G. (1958). Canadian Medical Association fournal, 79, 249

Nadler, S. H., and Moore, G. E. (1966). Annals of Surgery, 164, 482.

Old, L. J., Benacerraf, B., Clarke, D. A., Carswell, E. A., and Stockert, E. (1961). Cancer Research, 21, 1281.

Pruit, J. C., Mengoli, H. F., Carpenter, H. M., and Prater, T. (1963). Proceedings of the American Association for Cancer Research, 4, 54.

Sjögren, H. O., Hellström, I., and Klein, G. (1961). Experimental Coll Research, 23, 204.

Southam, C. M., Brunschwig, A., Levin, A. G., and Dizon, Q. S. (1966). Cancer (Philadelphia), 19, 1743.

Woodruff, M. F. A., and Boak, J. L. (1966). British fournal of Cancer, 20, 345.

Woodruff, M. F. A., and Nolan, B. (1963). Lancet, 2, 426

\title{
Oral Prostaglandins in the Induction of Labour
}

\author{
WALLACE BARR, W. C. M. K. NAISMITH
}

British Medical fournal, 1972, 2, 188-191

\section{Summary}

Prostaglandins $E_{2}$ and $F_{2} \alpha$ were administered by mouth to induce labour in 24 patients at or past term. The drugs were administered at two-hourly intervals in doses ranging from 0.5 to $1.5 \mathrm{mg}$ for prostaglandin $E_{2}$ and from 5 to $15 \mathrm{mg}$ for prostaglandin $F_{2} \alpha_{0}$ Of the 10 cases in which prostaglandin $E_{2}$ was used, labour was successfully induced in eight and there were no side effects. With prostaglandin $F_{2} \propto$ labour was induced in 12 of 14 patients nine of whom had gastrointestinal disturbance, mostly of mild degree. With both drugs the infant was apparently unaffected and Apgar scores were satisfactory. Uterine hypertonus was not observed and the postpartum blood loss was within normal limits.

\section{Introduction}

Recent clinical trials with prostaglandins $E_{2}$ and $F_{2} \propto$ have established their efficacy in inducing labour when administered by continuous intravenous infusion (Karim et al., 1968, 1970; Beazley et al., 1970; Embrey, 1970; Karim, 1970.) It has also

Queen Mother's Hospital, Glasgow G3 8SH

WALLACE BARR, F.R.C.s., F.R.C.o.G., Consultant Obstetrician and

W. C. M. K. NAISMITH, M.B., CH.B., M.R.C.o.G., Senior Registrar in Obstetrics and Gynaecology been reported (Karim, 1971; Karim and Sharma, 1971) that these drugs are effective when given by mouth, but the available evidence is scanty and there is as yet no published work on the subject from the Western hemisphere. The present study is of a preliminary trial of the action of both these prostaglandins in the induction of labour when administered by the oral route and reports the results obtained in 24 patients who were studied in detail.

\section{Patients and Materials}

Twenty-four patients were included in the series, of whom 10 were treated with prostaglandin $E_{2}$ and 14 with $F_{2} \alpha$. All were at or past term, and the reasons for induction are listed in Table II $\left(E_{2}\right)$ and Table III $\left(F_{2} \alpha\right)$. Ages ranged from 21 to 37 years, and all, with the exception of one primigravida, were healthy parous patients whose membranes were intact at the onset of treatment. In all cases the "inducibility" rating of the patient was assessed by the method of Bishop (1964) (see Table I) and

TABLE I-Inducibility Rating-Bishop's (1964) Method

\begin{tabular}{|c|c|c|c|c|c|}
\hline Factor & Score 0 & Score 1 & Score 2 & Score 3 & $\begin{array}{l}\text { Factor } \\
\text { Score }\end{array}$ \\
\hline $\begin{array}{ll}\text { Dilatation (cm) } \\
\text { Effacement } \\
\text { Station } & . . \\
\text { Consistency } & \ldots \\
\text { Position } & \ldots\end{array}$ & $\begin{array}{c}\text { Closed } \\
0-30 \% \\
-3 \\
\text { Firm } \\
\text { Posterior }\end{array}$ & $\begin{array}{c}1-2 \\
40-50 \% \\
\begin{array}{c}\text { Medium } \\
\text { Mid }\end{array}\end{array}$ & 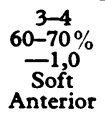 & $\begin{array}{c}5 \text { or more } \\
80 \% \text { or more } \\
+1,+2 \\
=\end{array}$ & $\begin{array}{l}0-3 \\
0-3 \\
0-3 \\
0-2 \\
0-2\end{array}$ \\
\hline \multicolumn{5}{|r|}{ Total score } & $0-13$ \\
\hline
\end{tabular}

-0-5 = unfavourable, 6-13 = favourable. 
uterine activity was monitored by external tocodynometry using either a Devices DC5 unit or a Sonicaid FM2 instrument which also provides continuous fetal heart recording. The external method of uterine recording was chosen since it was thought that the alternative method of introducing a cannula within the uterus might itself have contributed to the initiation of labour and so falsified the results. Spontaneous uterine activity was recorded for at least 30 minutes before the prostaglandins were administered and the recordings were continued in all cases until delivery, or until the drug was discontinued. During induction all cases were subject to normal nursing care, and every 15 minutes observations of maternal and fetal well-being were recorded. Blood biochemistry and haematology were recorded before induction and 12 hours post partum. These are described below.

\section{Prostaglandin E,}

\section{PREPARATION AND DOSAGE}

Prostaglandin $\mathrm{E}_{2}$ was prepared immediately before use as an $0.5-\mathrm{mg} / \mathrm{ml}$ solution in ethanol, and the appropriate dose was added at the bedside to a convenient quantity of drinking water (about $100 \mathrm{ml}$ ) to provide a clear almost tasteless fluid. A test dose of $0.5 \mathrm{mg}$ was followed 30 minutes later by a further test dose of $1 \mathrm{mg}$. Thereafter, dependent on uterine response, doses of 1 or $1.5 \mathrm{mg}$ were swallowed at intervals of two hours until the patient was considered to be in active labour, as indicated by dilatation of the cervix and by the activity of the uterine muscle as recorded by tocography. At this stage amniotomy was performed.

\section{RESULTS}

The results obtained in the 10 cases investigated are shown in Table II. It will be seen that in Cases 1 to 8 orderly uterine activity was readily established and resulted in normal delivery. Fig. 1 shows a tracing which is typical of the findings obtained.

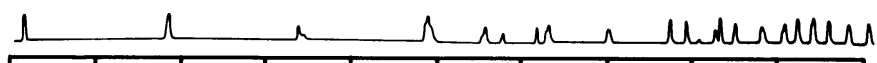

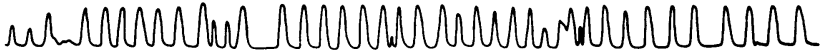

5 Minute intervals

$$
\text { FIG. 1-Typical tocographic tracing. }
$$

The time taken from the onset of induction until delivery ranged from 4 hours 27 minutes to 16 hours 47 minutes, with a mean of 11 hours 36 minutes. No patient received more than seven doses $(9 \mathrm{mg})$ of the drug. In Case 8 the supply of prostaglandin became exhausted when the cervix was $6 \mathrm{~cm}$ dilated and
Syntocinon infusion was then begun, with delivery ensuing 68 minutes later.

The remaining two cases must be classed as failures. Case 9 had almost continuous vomiting during the course of the attempted induction and it transpired that this patient had behaved similarly throughout her four previous labours. In retrospect she was not a suitable candidate for any kind of oral treatment, and absorption must have been impaired by repeated vomiting. On the following day amniotomy and escalating dosage of int ravenous Syntocinon resulted in normal spontaneous delivery after 5 hours 44 minutes.

Case 10 was the only primigravida in the series. Amniotomy with subsequent intravenous Syntocinon infusion had originally been intended and the former was attempted, but proved to be impossible on account of a high tightly-closed cervix and a high free-presenting head. With $0.5-\mathrm{mg}$ aliquots of prostaglandin $\mathrm{E}_{\text {, }}$ regular contractions were induced, but any increase above this dosage produced excessive and irregular uterine activity with transient bradycardia. This is illustrated in Fig. 2. Although

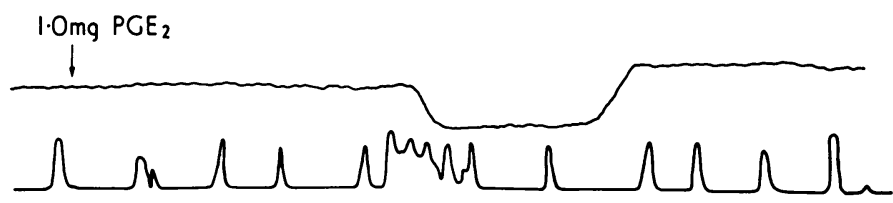

5 Minute intervals

FIG. 2-Case 10. Effect of $1 \mathrm{mg}$ of prostaglandin $\mathrm{E}_{2}$

it would seem that the contraction baseline does not return to the normal resting level betwen contractions, this is an artefact associated with the method of external tocography which was used; there was no evidence of uterine hypertonus. After five doses $\left(5 \mathrm{mg}\right.$ ) of prostaglandin $\mathrm{E}_{2}$ the cervix had dilated sufficiently to allow amniotomy, and thereafter intravenous Syntocinon infusion was begun. However, within eight minutes there was recurrence of excessive uterine activity similar to that seen with the increased dosage of $E_{2}$ and this was coincident with fetal bradycardia, the heart rate dropping to 80 beats per minute (see Fig. 3). After 14 minutes the infusion was discon-

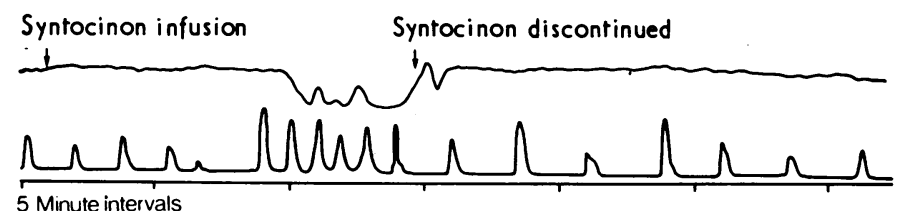

FIG. 3-Case 10. Effect of Syntocinon infusion.

tinued and lower-segment caesarean section performed, securing an active healthy infant. Postnatal pelvimetry showed a very adverse pelvis of android configuration.

TABLE II-Prostaglandin $E_{2}$

\begin{tabular}{|c|c|c|c|c|c|c|c|c|c|c|}
\hline $\begin{array}{l}\text { Case } \\
\text { No. }\end{array}$ & Age & Parity & $\begin{array}{c}\text { Maturity } \\
\text { (weeks) }\end{array}$ & $\begin{array}{l}\text { Indication } \\
\text { for } \\
\text { Induction }\end{array}$ & $\begin{array}{c}\text { Inducibility } \\
\text { Rating-Bishop }\end{array}$ & $\begin{array}{l}\text { No of } \\
\text { Oral Doses }\end{array}$ & $\begin{array}{l}\text { Induction } \\
\text { Delivery } \\
\text { Interval } \\
\text { Hr Min }\end{array}$ & $\begin{array}{c}\text { Amniotomy } \\
\text { Delivery } \\
\text { Interval } \\
\text { Hr Min }\end{array}$ & $\begin{array}{l}\text { Apgar } \\
\text { Score } \\
5 \text { min }\end{array}$ & $\begin{array}{c}\text { Mode } \\
\text { of } \\
\text { Delivery }\end{array}$ \\
\hline $\begin{array}{l}1 \\
2 \\
3 \\
4 \\
5 \\
6 \\
7 \\
8\end{array}$ & $\begin{array}{l}28 \\
21 \\
28 \\
34 \\
23 \\
26 \\
32 \\
28\end{array}$ & $\begin{array}{l}3+0 \\
1+0 \\
1+0 \\
3+1 \\
1+0 \\
1+0 \\
2+1 \\
1+0\end{array}$ & $\begin{array}{l}41+ \\
41+ \\
41+ \\
40 \\
43 \\
41+ \\
40 \\
40\end{array}$ & $\begin{array}{l}\text { Past dates } \\
\text { " " } \\
\text { Age " } \\
\text { Past dates } \\
\text { Rhesus" } \\
\text { " }\end{array}$ & $\begin{array}{l}4 \\
5 \\
5 \\
5 \\
9 \\
8 \\
5 \\
4\end{array}$ & $\begin{array}{l}3 \\
4 \\
4 \\
6 \\
6 \\
4 \\
7 \\
6(+\end{array}$ & $\begin{array}{rr}4 & 27 \\
11 & 8 \\
9 & 46 \\
12 & 54 \\
12 & 19 \\
9 & 14 \\
16 & 28 \\
16 & 47\end{array}$ & $\begin{array}{rr}0 & 27 \\
2 & 36 \\
1 & 31 \\
4 & 24 \\
3 & 49 \\
2 & 24 \\
10 & 58 \\
11 & 17\end{array}$ & $\begin{array}{r}10 \\
10 \\
10 \\
10 \\
8 \\
9 \\
10 \\
7\end{array}$ & $\begin{array}{l}\text { s.v.D. } \\
\text { s.v.D. } \\
\text { s.v.D. } \\
\text { s.v.D. } \\
\text { s.v.D. } \\
\text { s.v.D. } \\
\text { s.v.D.D. }\end{array}$ \\
\hline $\begin{array}{r}9 \\
10\end{array}$ & $\begin{array}{l}36 \\
32\end{array}$ & $\begin{array}{l}4+0 \\
0+0\end{array}$ & $\begin{array}{l}40 \\
40\end{array}$ & Age & $\begin{array}{l}2 \\
0\end{array}$ & 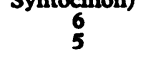 & $\begin{array}{l}\text { Failure } \\
\text { Failure }\end{array}$ & $=$ & $\begin{array}{l}10 \\
10\end{array}$ & L.U.V.D.C.s. \\
\hline
\end{tabular}

S.V.D. = Spontaneous vaginal delivery. L.U.S.C.S. = Lower uterine segment caearean section. 


\section{SIDE EFFECTS}

Maternal.-Apart from Case 9, whose tendency to vomit in labour should probably have excluded her from the trial, no side effects were recorded. The maternal heart rate and blood pressure were unaffected, and in three cases the following laboratory estimations were recorded before and also after treatinent. Blood chemistry: serum creatinine, urea, glucose, bilirubin, alkaline phosphatase, S.G.O.T., and S.G.P.T. Haematology: haemoglobin, packed cell volume, white cell count (total and differential), and platelet count. Urine analysis: albumin, sugar, and acetone. Electrolytes: serum sodium, potassium, chloride, and $\mathrm{CO}_{2}$ content. In no case was there a significant alteration after prostaglandin $\mathrm{E}_{2}$ therapy. There was no case of abnormal postpartum loss of blood, and no evidence of uterine hypertonicity in any case.

Fetal.-As shown in Table II the Apgar scores at five minutes were all in the satisfactory range. Routine recording of the fetal heart rate throughout labour showed no significant variation except for that described in Case 10.

\section{Prostaglandin $\mathrm{F}_{2} \alpha$}

\section{PREPARATION AND DOSAGE}

Initially it was attempted to administer prostaglandin $F_{2} \alpha$ in the same manner as prostaglandin $\mathrm{E}_{2}$-namely, in the form of a draught of water containing the drug-but in the first three patients this produced rapid onset of vomiting and diarrhoea of such severity that the drug had to be discontinued and alternative methods of induction used. These cases have not been included in the series.

Thereafter the drug was administered in capsule form, each capsule containing $5 \mathrm{mg}$ of prostaglandin $\mathrm{F}_{2} \alpha$. A test dose of $5 \mathrm{mg}$ was followed in half an hour by a further dose of $10 \mathrm{mg}$, and, dependent on uterine response, subsequent doses of $15 \mathrm{mg}$ were administered every two hours until, as with $\mathrm{E}_{2}$, labour was established and amniotomy was undertaken.

\section{RESULTS}

Fourteen patients were treated and the results are shown in Table III. In 12 cases labour was readily established and in all but one resulted in normal delivery, the time from induction to delivery ranging from 3 hours 45 minutes to 14 hours 53 minutes, with a mean of 11 hours 18 minutes. Fig. 4 shows sample recordings of the uterine contractions from Case 12 . The exception was Case 13, who responded well to the drug and in 10 hours 30 minutes had reached full dilatation of the cervix, but fetal bradycardia then developed and the head had failed to engage. Caesarean section produced a healthy male child weighing no less than $4.36 \mathrm{~kg}$. In Case 19 prostaglandin $F_{2} \alpha$ was only partially successful, regular contractions being established, but by 18 hours the active phase had not ensued. Thereafter intravenous
Syntocinon was administered and spontaneous delivery occurred 100 minutes later. The remaining case (No. 20) was a failure and the only response to six doses of $\mathrm{F}_{2} \alpha$ was distressing diarrhoea. Syntocinon in escalating dosage was then begun, resulting in spontaneous delivery six hours later.
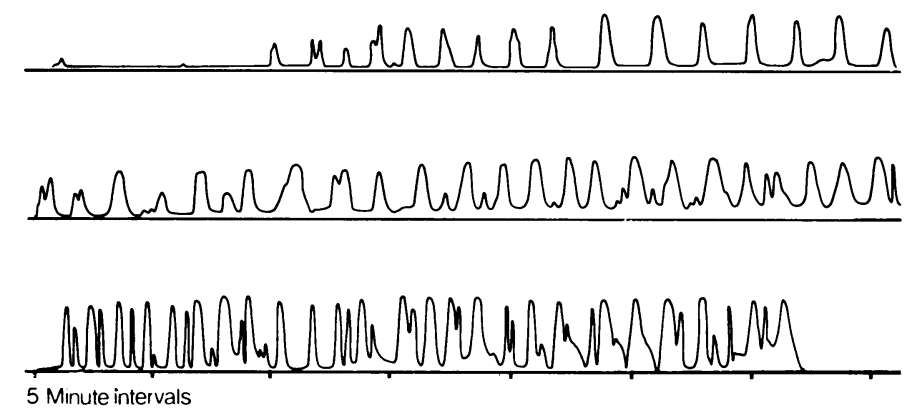

FIG. 4-Case 12. Sample recording of uterine contractions.

\section{SIDE EFFECTS}

Maternal.-Mild gastrointestinal disturbance was noted in 9 of the 14 patients treated. This took the form of nausea with occasional vomiting or loose bowel motions. Only one patient (Case 20) was seriously inconvenienced. The usual time of onset of these symptoms was after three to five doses of prostaglandin $\mathrm{F}_{2} \alpha$. There were no other side effects. Blood pressure and heart rate remained unaffected. In 11 of the 14 patients pretreatment and posttreatment blood chemistry, haematology, urine analysis, and electrolytes were evaluated as detailed for prostaglandin $E_{2}$. In no case was there significant alteration. There was no abnormal postpartum blood loss and no evidence of uterine hypertonicity during labour.

Fetal.-Observations on the fetal well-being were conducted throughout labour (Table III). Only in Case 13, described above, was there fetal bradycardia, and the Apgar score at five minutes was 2 . In the remaining cases the Apgar scores at five minutes were 10 ( 9 cases), 9 ( 2 cases), and 8 ( 2 cases).

\section{Discussion}

To the best of our knowledge there have been only two publications describing the clinical use of oral prostaglandins in the induction of labour. In the first of these Karim (1971) explored the effect of these drugs in a small pilot series of six cases, and in the second paper Karim and Sharma (1971) reported on 100 cases, 80 with prostaglandin $E_{2}$, of which 79 were successful, and 20 with $F_{2} \alpha$, of which 16 were successful. In the present series our dosage regimen with $\mathrm{F}_{2} \alpha$ was closely similar to that of Karim and our results were similar, labour being induced successfully in 12 out of 14 cases. However, with $E_{2}$, despite a considerable increase in dosage, we were unable to match the

TABLE III-Prostaglandin $F_{2} \alpha$

\begin{tabular}{|c|c|c|c|c|c|c|c|c|c|c|c|}
\hline $\begin{array}{l}\text { Case } \\
\text { No. }\end{array}$ & Age & Parity & $\begin{array}{c}\text { Maturity } \\
\text { (weeks) }\end{array}$ & $\begin{array}{l}\text { Indication } \\
\text { for } \\
\text { Induction }\end{array}$ & $\begin{array}{c}\text { Inducibility } \\
\text { Rating-Bishop }\end{array}$ & $\begin{array}{l}\text { No. of } \\
\text { Doses of } \\
\text { PG F }_{2} \alpha\end{array}$ & $\begin{array}{l}\text { Indu } \\
\text { Deli } \\
\text { Inte } \\
\mathbf{H r}\end{array}$ & $\begin{array}{l}\text { ction } \\
\text { very } \\
\text { erval } \\
\text { Min }\end{array}$ & $\begin{array}{c}\text { Amniotomy } \\
\text { Delivery } \\
\text { Interval } \\
\text { Hr Min }\end{array}$ & $\begin{array}{l}\text { Apgar } \\
\text { Score } \\
5 \text { min }\end{array}$ & $\begin{array}{c}\text { Mode } \\
\text { of } \\
\text { Delivery }\end{array}$ \\
\hline $\begin{array}{l}11 \\
12 \\
13 \\
14 \\
15 \\
16 \\
17 \\
18 \\
19 \\
20 \\
21 \\
22 \\
23 \\
24\end{array}$ & $\begin{array}{l}26 \\
32 \\
30 \\
26 \\
32 \\
29 \\
37 \\
24 \\
26 \\
32 \\
21 \\
34 \\
23 \\
32\end{array}$ & $\begin{array}{l}1+1 \\
4+0 \\
1+0 \\
1+0 \\
1+0 \\
4+0 \\
6+0 \\
1+0 \\
1+1 \\
1+0 \\
2+0 \\
5+1 \\
1+0 \\
4+1\end{array}$ & $\begin{array}{l}41+ \\
41+ \\
42 \\
41 \\
41+ \\
41+ \\
41+ \\
40 \\
42 \\
40 \\
40 \\
40 \\
42 \\
41+\end{array}$ & $\begin{array}{l}\text { Past dates } \\
\text { " " " } \\
\text { " " } \\
\text { " " } \\
\text { "” "’ } \\
\text { Pre-eclampsia } \\
\text { Past dates } \\
\text { Pre-eclampsia } \\
\text { Age" } \\
\text { Past dates } \\
\text { " " }\end{array}$ & $\begin{array}{l}6 \\
6 \\
7 \\
4 \\
4 \\
6 \\
6 \\
8 \\
6 \\
3 \\
7 \\
5 \\
4 \\
5\end{array}$ & $\begin{array}{l}3 \\
4 \\
6 \\
6 \\
6 \\
3 \\
7 \\
3 \\
7 \\
6 \\
6 \\
6 \\
8 \\
4\end{array}$ & $\begin{array}{r}5 \\
6 \\
10 \\
10 \\
10 \\
10 \\
14 \\
3 \\
19 \\
17 \\
11 \\
9 \\
14 \\
5\end{array}$ & $\begin{array}{l}33 \\
25 \\
30 \\
55 \\
35 \\
43 \\
53 \\
45 \\
45 \\
13 \\
52 \\
59 \\
35 \\
43\end{array}$ & $\begin{array}{rr}\overline{1} & 28 \\
\overline{3} & 22 \\
3 & 55 \\
3 & 35 \\
2 & 20 \\
\frac{5}{8} & 03 \\
\frac{13}{13} & 30 \\
10 & 03 \\
3 & 24 \\
3 & 04 \\
7 & 35 \\
\text { No amniot. }\end{array}$ & $\begin{array}{r}10 \\
9 \\
2 \\
9 \\
8 \\
10 \\
10 \\
10 \\
10 \\
10 \\
8 \\
10 \\
10 \\
10\end{array}$ & $\begin{array}{l}\text { S.V.D. } \\
\text { S.v.D.D. } \\
\text { L.V.D. } \\
\text { s.v.D. } \\
\text { s.v.D. } \\
\text { s.v.D. } \\
\text { s.v.D. } \\
\text { s.v.D. } \\
\text { s.v.D. } \\
\text { s.v.D. } \\
\text { s.v.D. } \\
\text { s.v.D. } \\
\text { s.v.D. }\end{array}$ \\
\hline
\end{tabular}


high success rate of Karim as we had two failures in 10 cases. Moreover, all but one of our patients were parous, whereas two-thirds of Karim's group were primigravidae. It may be that persistence with the drug for a longer time would have ultimately brought success, and Karim described a case in which prostaglandin $\mathrm{E}_{2}$ was given in repeated doses of 0.5 to $1.5 \mathrm{mg}$ over a period of two days.

We do not feel that it is justifiable to persist with any single method of induction for more than six to eight hours, and if labour has not been established within that time then alternative methods of induction should be sought. However, with further experience of these drugs it is probable that more effective dose schedules will be evolved without loss of safety to mother or infant. Neither drug seemed to have an adverse effect on mother or infant, but with $F_{2} \propto$ vomiting and diarrhoea occurred in most cases and this might prove to be a limiting factor in the number of doses administered.

It was also noted that the small number of patients who failed to respond to prostaglandin and were subsequently treated with intravenous infusion of Syntocinon proceeded rapidly to delivery. This supports the theory, at present under investigation, that there may be a synergistic action between these drugs.

In conclusion, there is no doubt that prostaglandins $E_{2}$ and $F_{2} \alpha$, given by mouth, are often effective in inducing labour. Extensive trials are now in progress and it remains to be seen what role they will ultimately assume in the search for the ideal induction agent, which must be safe, effective, and convenient to use.

We are indebted to Dr. Margaret Lawson, who gave unstintingly of her time and energy to monitor these patients during labour. We also thank Mrs. Davidson and her staff in the labour suite of the Queen Mother's Hospital, and Mr. Sheerlaw, the hospital pharmacist, and his staff, who prepared the drugs for oral administration. Our thanks are also due to our consultant colleagues for permission to include patients under their care in the trial and to Messrs. Upjohn Ltd., who supplied the prostaglandins.

\section{References}

Beazley, J. M., Dewhurst, C. J., and Gillespie, A. (1970). Fournal of Obstetrics and Gynaecology of the British Commonwealth, 77, 193.

Bishop, E. H. (1964). Obstetrics and Gynecology, 24, 266.

Embrey, M. P. (1970). British Medicalfournal, 2, 256.

Karim, S. M. M. (1970). Conference on Prostaglandins, New York Academy of Sciences.

Karim, S. M. M. (1971). fournal of Obstetrics and Gynaecology of the British Commonwealth, 78, 289.

Karim, S. M. M., Hillier, K., Trussell, R. R., Patel, R. C., and Tamusange, S. (1970). Fournal of Obstetrics and Gynaecology of the British Commonwealth, 77, 200.

Karim, S. M. M., and Sharma, S. D. (1971). British Medical fournal, 1, 260.

Karim, S. M. M., Trussell, R. R., Patel, R. C., and Hillier, K. (1968). British Medical fournal, 4, 621 .

\title{
Amniotomy and Oral Prostaglandin $\mathbf{E}_{2}$ Titration for Induction of Labour
}

\author{
IAN CRAFT
}

British Medical fournal, 1972, 2, 191-194

\section{Summary}

The efficacy of oral prostaglandin $E_{2}$ used on a titration basis in association with amniotomy for the induction of labour was investigated in a series of 50 patients. Induction was successful in 29 out of 32 primigravid and 17 out of 18 multigravid patients. The mean inductiondelivery intervals in successful cases were $10 \frac{1}{2}$ and 6 hours respectively. There were no significant effects on the fetuses.

\section{Introduction}

The induction of labour by the intravenous infusion of prostaglandins is now well documented (Karim et al., 1968; 1970; Beazley et al., 1970; Embrey, 1970; Karim, 1970). Other studies have compared the effectiveness of using prostaglandin $\mathbf{E}_{2}$ with oxytocin administered by this route (Beazley and Gillespie, 1971; Craft et al., 1971; Karim, 1971).

Karim and Sharma (1971) reported the induction of labour with oral prostaglandins. This was successful in 79 out of 80 patients treated with prostaglandin $E_{2}$ and in 16 out of 20 patients treated with $F_{2} \alpha$. There were no serious side effects. Amniotomy was not performed at the outset in this study.

Since current obstetric practice is tending to favour an active approach to induction consisting of membrane rupture and simultaneous oxytocic stimulation, a study was undertaken into

\footnotetext{
Department of Obstetrics and Gynaecology, Kingston Hospital,
Kingston, Surrey

IAN CRAFT, F.R.C.S., M.R.c.o.G., Senior Registrar
}

the efficacy of oral prostaglandins used on a titration basis in association with amniotomy. Initially prostaglandin $F_{2} \alpha$ capsules were used but because of gastrointestinal side effects and limited success experienced with this formulation it was discontinued. This paper reports the results of using prostaglandin $E_{2}$ orally in association with amniotomy in a series of 50 patients requiring induction.

\section{Patients and Methods}

The patients, who were unselected, were induced at or near term for a variety of reasons. Their inclusion in this study was based solely on their willingness to act in a volunteer capacity and not on other factors known to affect the outcome of induction-for example, favourability of the cervix, descent of the presenting part, maturity, etc. Of the total, 32 patients were primigravid and 18 multigravid. The presentation was cephalic in each instance, including three cases of multiple pregnancy.

A standard method of induction was undertaken by me in each subject. After premedication with intravenous diazepam $10 \mathrm{mg}$ forewater rupture was performed. At the same time a prelabour score (Bishop, 1964), indicating an inducibility rating, was assessed by noting the state of the factors recorded in Table I. No factor was given extra weighting in the calculation of this score. Simultaneously oral prostaglandin $\mathrm{E}_{2}$ was begun according to the titration schedule described below.

The progress of labour was assessed by noting the strength and frequency of uterine contractions, alteration in the state of the cervix, and descent of the presenting part. Vaginal examinations were performed every four hours as a routine, and at intervals between to confirm full dilatation if suspected, usually by the same observer. Initially uterine contractions and fetal heart recordings were monitored continuously throughout 